\title{
DIGITAL POLITICAL PARTICIPATION AND THE DIGITAL DIVIDE: INSIGHTS FROM THE CAMBODIA CASE
}

\author{
Marc Pinol Rovira ${ }^{a}$
}

\begin{abstract}
Political participation in Cambodia is broadly characterised by high voter turnouts and limited democratic constitutionalism to ensure that elections are inclusive and a fairly contested process. The popularisation of digital media and tools profoundly impacted political participation in Cambodia: on the one hand, digital media improved people's political engagement - for example, with organisational skills to take part in political rallies - but, on the other hand, challenges like digital surveillance or unequal opportunities to benefit from digital media emerged. This article uses existing literature to explain how digital media has changed political participation, and primary data from in-depth interviews to key members of civil society to analyse the impact of the digital divide on political participation. It is suggested that digital media is valuable opportunity to improve democratic governance, but the digital divide is limiting its democratising capabilities; young citizens with critical thinking skills are more likely to benefit from digital democracy, while adults with lower critical engagement with digital media are more exposed to threats like fake news. This article feedbacks debates on political participation in the digital era and, more broadly, on the democratisation capabilities of digital media, and endorses the views of techno-sceptics, who acknowledge the opportunities of digital democracy, but they show great(er) concern for the challenges.
\end{abstract}

Keywords: political participation, digital divide, digital media, democracy, Cambodia

\section{INTRODUCTION}

Cambodia's history is tumultuous: from the great Khmer Empire that expanded across Southeast Asia in the $12^{\text {th }}$ century (Jacques \& Lafond, 2007) to its decline - ninety years of colonial rule; the genocide during the Khmer Rouge regime; civil war in the 1970s; and the Vietnamese occupation during the 1980s exemplify it (Chandler, 1993; Strangio, 2020; Vickery, 1999). An examination of history provides context to understand the major political developments in the country, and how they are still relevant today: decades of conflict and authoritarian rule that resulted in power dynamics that have placed a disproportionate amount of power in the hands of elites; lack of democratic tradition that translated in political participation mostly based on electoral democracy; and, more recently, why the popularisation of digital media to practise politics has shaken the current system of governance.

The use of digital media to practise politics, or digital democracy (Freeman \& Quirke, 2013, P.144), which emerged in Cambodia in the early 2010s was a major political development; it provided civil society with new opportunities to engage in politics but, more recently, it has also put pressure on civil society since it has been

a Marc Pinol Rovira (marc.pinol@bristol.ac.uk) is a Doctoral Candidate and Assistant Teacher, the University Bristol, United Kingdom. 
widely used for surveillance purposes, thus negatively impacting how citizens use digital resources for political action (Cambodian Centre for Independent Media, 2018; Shahbaz, 2018). However, not all citizens are benefitting equally from digital democracy. Inequalities regarding access to digital infrastructure, age, or digital literacy (DiMaggio \& Hargittai, 2001) have negatively impacted people's digital experiences.

Given these developments, it has become necessary to understand the characteristics of the digital divide and how it affects political participation in the digital era. Accordingly, this paper engages with digital political participation and the digital divide; the first half uses existing literature to explain why digital democracy became a relevant political development in the early 2010 s, while the second half uses primary data to make a qualitative analysis of the digital divide using age and education. To make the empirical case, I use the experiences shared by ordinary citizens and spokespeople of civil society organisations (CSO), who offered their views on digital democracy. Overall, this article demonstrates that regardless of the opportunities associated to digital democracy, challenges still eclipse opportunities, thus not allowing democracy to flourish as it had been expected. This discussion is relevant since it feedbacks existing debates on the opportunities and challenges of digital political engagement and, more broadly, on the democratising capabilities of digital media.

\section{CONCEPTUAL AND THEORETICAL FRAMEWORK}

From a theoretical standpoint, this article addresses three core themes: first, political participation in digital environments - which also includes analogue spaces, since the two are interlinked; second, the digital divide as a characteristic of digital democracy and as a challenge to digital political participation; and third, the democratising capabilities of digital democracy, and how these are being challenged.

\section{Digital political participation}

Political participations are those voluntary actions that, directly or indirectly, aimed at shaping governmental policies and/or influencing political perceptions (Bong \& Sen, 2017; Casteltrione, 2015; van Deth, 2016; Whiteley, 2005). Voting in elections is an example of the former, while hosting and/or participating in a political forum - either online or physically - exemplifies the latter. Therefore, participation is not limited to electoral democracy, and constitutional liberalism is equally important "to protect an individual's autonomy to and dignity against coercion" (Zakaria, 2007, p. 19). Actions such as participating in political rallies, joining a party, or taking part in forums are equally relevant for political participation since these are actions that allow citizens to shape public policies and, ultimately, make informed political choices (Huntington, 1993). Electoral democracy and constitutional liberalism are therefore complementary; political liberties are necessary so that all members of civil society can engage in the public space freely and make elections meaningful. Put differently, direct democracy and representative democracy are complementary. Therefore, this view attempts to make participation as inclusive as possible - a key characteristics of functioning democracies (Dryzek \& List, 2003, Putnam, 2000). 
Over the last two decades, digital tools and media have shaped how political participation takes place. "Digital democracy" (Freeman \& Quirke, 2013, p. 144), defined as "the practice of democracy using digital tools and technologies" (Simon et al., 2017, p. 11), has emerged as a result of the interaction between digital media and politics. Some researchers (Meijer et al., 2009; Norris, 2010) have observed that citizens have greatly benefited from information and communication technology (ICT) in the political realm; they have increased their civic engagement and, consequently, have had greater leverage over governmental institutions. But, digital democracy does not concern peoples' political engagement, and other researchers (Freeman \& Quirke, 2013) have devised complementary conceptualisations of digital democracy, such as e-government (delivering governmental information through electronic means) and e-governance (the regulations that both government and citizens establish). To limit the scope of this study, this article focuses on the impact of digital democracy on civil society.

A widely acknowledged opportunity of digital media is that is has become a medium for citizens to voice their political views, as well as to engage citizens in active political actions (Papacharissi, 2013). Nonetheless, other studies are more cautious and argue that the internet is effective to express political views, but less effective to trigger active participation that results in meaningful impact (Bennett, 2012; Marichal, 2013). Besides distinguishing different types and degrees of political engagement, literature also notes that online and offline participation rarely work independently, as since digital media replicates traditional offline cases of participation in the online (Gibson \& Cantijoch, 2013; Gil de Zúñiga et al., 2012). For example, Facebook has become a voting persuasion tool, instead of hosting a face-toface event. Tailoring digital political participation to the Cambodia case, existing studies contend that digital media - Facebook, mostly - has proved to be an effective tool for citizens to access a wider variety of news outlets and information (Hughes \& Eng, 2018; Soeung, 2013; Vong \& Hok, 2018). Moreover, Facebook was also key in mobilising people to attend analogue political activities like the pro-CNRP rallies in the context of the elections of 2013 (Soeung, 2013).

\section{The digital divide}

Digital democracy also presents challenges. One is that in authoritarian regimes, autocratic leaders have made use of digital media for non-democratic ends. For example, the co-optation of the digital space has allowed to target critics and dissenting voices, thus adding pressure to civil and political liberties (Altheide, 2013; Çelik, 2020; Nyabola, 2018). In Cambodia, the co-optation of digital media and crackdown on liberties happened after the elections of 2013 and peaked in 2017, just one year before the general elections of 2018; channels for political engagement were closed and, consequently, opportunities for political participation were reduced, thus contributing to a democratic regression (Cambodian Centre for Independent Media, 2018; Croissant, 2018; Lamb, 2018; Shahbaz, 2018).

Another challenge to political participation that is often less obvious is the digital divide - a challenge that impacts citizen's possibilities to fully benefit from digital politics. The digital divide contemplates digital inequalities like differences between those who have better access to the internet than others (DiMaggio \& Hargittai, 2001). But, apart from digital infrastructure, there are more factors that 
contribute to the digital divide: research also indicates that further inequalities such as education and literacy (Hargittai, 2010; J. A. G. M. van Dijk, 2006; Wijers, 2010), the rural-urban divide (Chinn \& Fairlie, 2006), and age (Mossberger et al., 2003; Weaver Lariscy et al., 2011) also create digital inequalities. All these factors are normally interlinked and they all contribute to citizen's digital experiences, which is why the "causes of the digital divide are part of a more complicated assembly of societal processes" (Wijers, 2010, p. 337).

\section{Digital democracy - does it strengthen or undermine democracy?}

The debate on how digital media is influencing democracy presents two standpoints. First, those who highlight the democratising capabilities of digital media emphasise qualities like being able to access endless political content, producing and sharing content almost instantaneously - thus becoming producers and broadcasters networking, and coordinating political events are some of the opportunities that, from a utopian perspective, make digital media an essential to improve democracy (Shirky, 2011; Simon et al., 2017; S. van Dijk Johhannes, 2012). Second, the dystopian perspective does not negate most benefits pointed out by techno-supporters; they acknowledge them, but they stress challenges such as surveillance, lack of meaningful engagement, or censorship (Gladwell, 2010; Guess et al., 2018; Morozov, 2011). However, the views of digital technology that feed this debate have dramatically changed since digital media first began interacting with the political sphere: "in only five years social media have gone - in the popular imagination at least - from being a way for pro-democratic forces to fight autocrats to being a tool of outside actors who want to attack democracies" (Tucker et al., 2017, p. 47). In other words, digital media has been described as technology that can challenge tyranny, but also as a source for censorship (Diamond, 2010). Literature on digital democracy is therefore an uninterrupted back and forth between opportunities and challenges that respond to chancing social and political conditions. Therefore, the overall idea is to acknowledge that digital tools have the capacity to empower citizens, while at the same time they can also be destructive tools if not used properly (Murdoch, 2010).

Therefore, the analysis of digital democracy must consider these opportunities and challenges and, more importantly, it must acknowledge that they change very quickly, thus shaping the debate on the democratising capabilities of digital media. The digital divide is one of Cambodia's current challenges to the digital engagement and political participation of its people. Analysing the digital divide involves analysing how people are using digital media with political ends and, more importantly, which factors shape their digital engagement. Fixing the digital divide is not the ultimate answer to improve digital political participation, but it is one factor that contributes towards finding out how digital media contributes to the country's democratic development.

\section{METHODOLOGY}

The Cambodia case has two sections: in the first one, I use existing literature to contextualise the popularisation of digital democracy in Cambodia, and why it mattered for political participation. In the second part, I use a dataset that consists of forty-seven semi-structured interviews to several members of the civil society. I 
conducted these interviews in the capital city, Phnom Penh, between June and September 2019. Respondents are categorised into two groups:

1) Ordinary citizens. Permanent residents in the city of Phnom Penh, regardless of their province of birth. The only requirement was that they should own a smartphone with a data plan. I kept relative balance in terms of age (young respondents are those between 19 and 35, while adults are those who are 35 and older), gender (male and female), and level of formal education (those with a primary school diploma or lower were considered as "low formal education", and those with a degree higher than primary education were considered as "high formal education").

2) Civil society organizations (CSO). Informants include spokespeople from NGOs, INGOs, think tanks, activists, grassroots leaders, social media influencers, academics, journalists, and politicians from opposition parties. I do not include representatives of the state sector since this goes beyond the scope of the study, because of limited resources (time and money), and because of safety concerns. However, I acknowledge this as a limitation of the study that can shed new lights for future research.

This methodological choice allows using a small sample to conduct a qualitative analysis of the digital divide and political participation. Therefore, outcomes are not intended to generalise. Instead, in-depth interviews with selected participants are effective to collect personal experiences and identify relevant issues that might be studied in future studies using alternative and/or complementary methods.

\section{THE CAMBODIA CASE: HOW DIGITAL MEDIA CHANGED POLITICAL PARTICIPATION}

\section{Cambodia's lack of power-sharing tradition}

Historically, power-sharing tradition in Cambodia has been rather weak (Strangio, 2020). Focusing on the post-colonial era (1953 onwards), different governments showed that democratic governance has not been the rule. Norodom Sihanouk was profoundly revered by most Cambodians due to his eminent role in the royal crusade for independence (Chandler, 1993), but he relied on a personalist style of leadership, and the amount of power that he was able to concentrate in his hands eclipsed the political, thus diluting the benefits of the separation of powers (Ayres, 2000; Kiernan, 2008). Lon Nol ousted Sihanouk from power in 1970 (McCabe \& Haffner, 2020), but the country quickly split between his supporters and the Khmer Rouge (Chandler, 1993; Kiernan, 2008) until 1975, when political tensions escalated to civil war. Conflict would last until 1979 when the Khmer Rouge took the capital city Phnom Penh (Kiernan, 2008). The communist regime of the Khmer Rouge ended in 1979 when Vietnamese troops occupied Cambodia (Strangio, 2020; Vickery, 1999). However, that was not the end of conflict in Cambodia, and Hanoi's satellite government in Phnom Penh would last until 1989, after long multi-party negotiations finally put an end to decades of violence and conflict in the country (Strangio, 2020). Postcolonialism was therefore characterised by dominant leaders, conflict, and authoritarianism. 
As I have mentioned earlier, a historical overview matters because it provides context to political context in the present time. The consequences of those years of conflict and authoritarianism are still shaping political participation today: research has shown that those Cambodian citizens who were victims of violent and distressing situations are more likely to experience fear and mistrust (Chhim, 2012, 2013; Kidron \& Kirmayer, 2019). According to Chhim (2013), victims associate fear and mistrust to politics ( $86 \%$ of his participants), something that alienates them from politics, thus making them less politically active (ibid). Moreover, it must also be considered that, while trauma is not genetically inherited, it can transcend time since it can be transmitted from generation to generation through one's behaviour and/or personality traits that have been developed (Scharf, 2007; Volkan, 2001). Put differently, the political consequences of authoritarian rule and lack of democratic governance in Cambodia are long lasting - in the empirical part, one informant exemplifies it. However, the 1990s were a major turning point.

In 1991, the Paris Peace Agreements (PPA) brought peace to Cambodia, and the United Nations Transitional Authority in Cambodia (UNTAC) would supervise the first democratic elections in 1993 (Chea, 2013). The Agreements put in place a democratic system whose blueprints were universal suffrage and civil and political liberties to ensure that everyone would be able to engage in politics freely and without coercion (Frost, 1992). Cambodia's democratic transition had positive and negative impacts. On the one hand, a major accomplishment was the celebration of regular elections that, since 1993 until today, have taken place every five years with remarkably high voter turnouts: 89.5\% in 1993 (Nohlen et al., 2001); 90\% in 1998 (Peou, 1998b); 83.2\% in 2003 (EU Election Observation Mission, 2003); 75\% in 2008 (COMFREL, 2008); 69.6\% in 2013 (McCargo, 2018); and 80.4\% in 2018 (ibid). On the other hand, challenges emerged, and cases of structural violence like harassment and coercion against dissenting voices have not been unheard of (Heder, 1995; Strangio, 2020). Direct violence became rarer, but it did not totally disappear: the most flagrant case was PM Hun Sen's violent coup to oust his co-prime minister in 1997 (Peou, 1998a). Compared to the post-PPA era, structural violence replaced direct violence in the 1990s - neopatrimonialism networks, elite entrenchment, and corruption, for example - which did prevent democracy to flourish, and also diluted the expectations on uncoerced political participation (Pak et al., 2007; Peou, 1998a, 1998c; Teng, 2015; Un, 2005).

Given the aforementioned positive and negative developments, the success of Cambodia's democratic transition has been disputed: in absolute terms, it cannot be argued that democracy in Cambodia has fully flourished but, if compared to the prePPA decades, there has been a relative democratic improvement. This improvement is relative because, regardless of the celebration of elections, Cambodia is still facing substantial democratic challenges: increased pressure on civil and political liberties over the last five years; media crackdown; surveillance; and dissenting voices being harassed are not uncommon (Freedom House, 2019; Human Rights Watch, 2018). Furthermore, the entrenchments of elites through neopatrimonialism networks and political clientelism are limiting the effectiveness of elections (Morgenbesser, 2017). Such mixed democratic outcomes reflect that "paradoxically, during the last decade in Southeast Asia, substantial political change, including increasing political participation, has often been accompanied by a narrowing of the channels for political 
contestation" (Jayasuriya and Rodan, 2007, p. 774), and Cambodia is no exception. However, in the early 2010s, the popularisation of digital media would profoundly alter political participation.

\section{The arrival and popularisation of digital tools and media}

Cambodia's digitalisation process began between the late 2000s and early 2010s (Phong et al., 2016). Only a decade later, as of 2020, the penetration index of smartphones is $128 \%$ (some users own multiple devices) or 21.2 million users out of 16.6 million people, and 58\% of its users use it to access the internet (We Are Social, 2020). The smartphone is, therefore, the first device of choice to access the Internet. Smartphones have boosted social networking sites (SNS), a type of "online community that relies on user contributions" (Brandtzæg \& Heim, 2009, p. 143). Data shows that, in Cambodia, Facebook ${ }^{\mathrm{i}}$ is the most widely used SNS with 9.2 million users in 2020, and it is capable of reaching up to $76 \%$ of the population. Other social media platforms like Instagram and Twitter only have 610,000 and 271,000 users, respectively (We Are Social, 2020). Another key factor that links smartphones and social media is that up to $92.6 \%$ of those who access SNS do it only via a smartphone ${ }^{\mathrm{ii}}$ (ibid).

Digital media soon interacted with the political sphere - hence the term "digital democracy" (Freeman \& Quirke, 2013, p. 144), or "e-democracy" (Norris, 2010 , p. 339) - especially in the context of the general elections of 2013. Two reasons made those commissions extraordinary: first, the results of the opposition Cambodia National Rescue Party (CNRP), iii led by Sam Rainsy, were outstanding and challenged the rule of the Cambodian People's Party (CPP) and PM Hun Sen for the first time: the CNRP obtained 55 seats, while the CPP obtained 68 (Al Jazeera, 2013). Second, digital media was quickly pointed out as a key factor that had shaped those electoral results (Asia Foundation, 2016; Hughes, 2013; Phong et al., 2016). Aside from being a source of entertainment (Brandtzæg \& Heim, 2009), digital media became a gateway to a wide selection of alternative narratives to governmental views provided by independent journalists, media outlets of foreign nature, bloggers, think tanks, NGO, etc. (Um, 2014). As Soeung (2013) points out, digital media became a mechanism to avoid government mouthpieces and censorship. Social media platforms - Facebook in particular - also proved to be efficient tools to organise mass political gatherings - for example, during the political campaign in 2013, the CNRP was able to mobilise thousands of supporters mostly via Facebook (ibid). Social media was therefore a tool that offered new possibilities to improve people's political engagement.

Cambodia's social characteristics explain why those developments became possible. According to Soeung (2016), demography was particularly relevant. Cambodia's median age is 26, and the majority of citizens are younger than 35 (CIA, 2020), which mattered because youth tend to be more digitally literate (Vong \& Hok, 2018) - I will address the age gap and digital literacy in the next section - thus more skilful to benefit from digital resources. Moreover, the age split was also crucial because many young citizens were alienated from the networks of the CPP compared to their older relatives and, consequently, anticipating their voting intentions for the 2013 elections was challenging (Hughes, 2013; Un, 2015; Vong \& Hok, 2018). That 
was "significant because it suggests that these sophisticated and well-practiced techniques of social control are not working as well as previously in rendering the electorate legible to the party" (Hughes, 2013) - something that affected participation, as the electoral results showed.

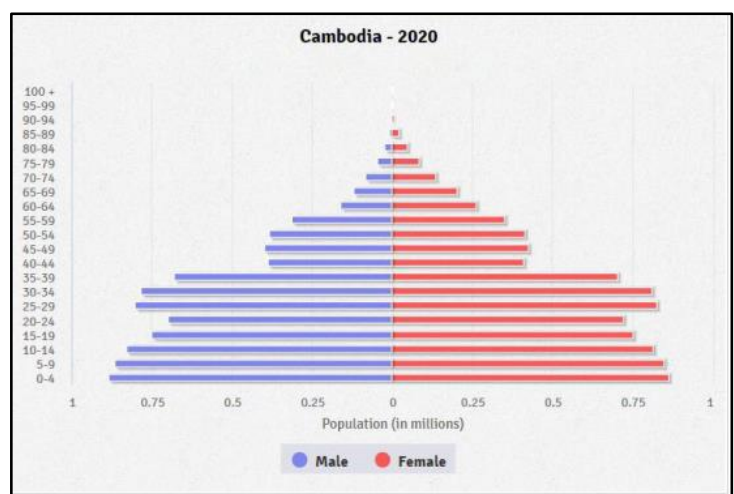

Figure 1: Cambodia's population pyramid in 2020 (CIA, 2020)

Following civil society's democratic push, the state sector adopted a digital strategy that, firstly, consisted of promoting government officials through Facebook pages, mostly to enhance their image and give an appearance of proximity (Soeung, 2016). However, several concerns were raised regarding the co-optation of the digital space. The degree of digital dominance that the state sector exercised before the commune (local) elections of 2018 forced many independent media outlets to close since digital platforms were used to prosecute online speech (Freedom House, 2019). The digital crackdown mattered because digital media had become a crucial mechanism from citizens and CSOs to reach their audience, to make their voices heard, to mobilise people, and, more broadly, to engage in politics (Human Rights Watch, 2018; Schoenberger et al., 2018).

The Cambodia case shows how the popularisation of digital tools and media initially translated into opportunities for political participation - especially applicable to countries with a poor democratic background. But, as the interaction between digital media and politics solidified, challenges became more visible. Internet capabilities are used for surveillance and, moreover, the digital divide made digital inequalities more evident. Therefore, looking at digital media exclusively as liberation technology (Diamond, 2010) has quickly become outdated, and it is necessary to examine these challenges to understand how they are threatening the opportunities of digital democracy. The next section looks at the digital divide in greater detail.

\section{THE DIGITAL DIVIDE IN CAMBODIA}

This section uses empirical evidence to describe and analyse the digital divide in Cambodia. The analysis of the interviews reveals that age - as mentioned in the previous section - is a key factor that explains the digital divide. Moreover, education and critical thinking in particular, plus the urban-rural split are other factors that provide further insights on the age split. The first variable of the digital divide that I will examine is age, and how youth have used digital media differently compared to adults. In the second half, I will explain education and geographical origin in relation to age. 


\section{The age factor: young and adult respondents}

Age is a determinant factor to predict political participation: broadly speaking, adult citizens are traditionally more politically active compared to youth (Diehl et al., 2019; Melo \& Stockemer, 2014). But with the popularisation of digital media, it has been found that youth are more politically engaged, especially through "unconventional" (Lee, 2017: 63) actions organised mainly by non-institutional actors (MacKinnon, 2007; Weaver Lariscy et al., 2011). According to the CSOs that were interviewed especially those working at grassroots level with young people - the age split has deeply shaped political participation in two ways. First, fear of politics: fear is predominantly found among old(er) citizens (35 and older) who have experienced the harshest years of authoritarian rule or, at least, the post-conflict era. The government often benefits from the chilling effect created through threats of going back to violent conflict should an opposition party win the elections. As a representative of an INGO commented, this strategy is more effective among adults since memories from the Khmer Rouge are more vivid:

"I think the new generation is doing better because they are less fearful of being attacked. We have seen lots of political platforms run by the ruling party... they usually go back to the Khmer Rouge, to create an atmosphere of fear saying that we have been through the Khmer Rouge regime, killings... and I [Prime Minister] am doing the good thing now... if you want to change to a new government, you may go back to that" (Participant 326, August 2019).

Age is therefore indicative of which citizen cohorts are more likely to respond to the "culture of fear" (Alves, 1990) that the state sector promotes and, consequently, avoid political interactions. For example, one young respondent explained that her parents and other relatives have often discouraged her from engaging in politics because "there is nothing we can [change] about it" (Participant 206, July 2019), and also because it can be dangerous. This is one example of fear being transmitted from an adult to a young citizen (Scharf, 2007). But social media was decisive in changing her perception and lack of engagement towards politics: the same participant also detailed that, thanks to her smartphone and access to digital media, she became "free", and that she also was able to search for alternative political views, explanations and, overall, engage more often in the day-to-day political activity of the country. To a certain extent, she was able to break the "climate of fear" (Participant 315, August 2019) that characterises politics in Cambodia, and engage more directly with politics.

Similar views were shared by adult respondents too: the main asset of digital media is that it provides access to a wide variety of news outlets and information on any topic. More importantly, respondents stressed the importance of having access to information sources that are not governmental mouthpieces (e.g.: Fresh News), since "media is controlled by the government, so they never say negative things about the government; they only show the good things" (Participant 207, Phnom, 2019), according to an adult participant. Then he added that "I only trust some sources; for example, Voice of America, Radio Free Asia, or France Radio [all these are of foreign nature]; I believe they broadcast the real information". According to a journalist, this is a basic but fundamental opportunity to access more reliable political information, 
since "Cambodia is no heaven for free press and journalists" (Participant 302, July 2019).

Age is therefore a highly relevant factor in the study of political participation and the digital divide. First of all, age can be indicative of which citizens are more likely to experience fear of politics and mistrust. Research has shown that those who have gone through distressing experiences like political conflict and authoritarian rule are less likely to engage actively in politics (Alves, 1990). Since the harshest years of violent conflict and authoritarianism were before the 1990s, those who have experienced conflict are adults and older citizens. Therefore, fear of politics explains adults' low(er) political engagement compared to youth, an outcome that contradicts broad participation theses that place adults as more politically active citizens (MacKinnon, 2007; Weaver Lariscy et al., 2011).

On the other hand, I have also shown that youth can be negatively influenced by the conservative views of their older relatives who encourage them not to engage in politics, thus negatively affecting political participation. However, the case of some young participants demonstrate that digital media has helped them to overcome the culture of political fear (Alves, 1990) - they became more independent, and gained knowledge, and interest in politics mostly through their smartphones. This endorses the thesis that digital media helped youth to engage more in politics (Weaver Lariscy et al., 2011). However, these findings are not conclusive on alternative forms of engagement, other than the online replica of analogue examples of participation. Therefore, more research is necessary on what "alternative" or "unconventional" means in the digital context of Cambodian. Overall, age is an important element that contributes to widening the digital divide: while some young people have been able to embrace digital media to engage more in politics, adults are more likely to fall behind because of fear, and also because they are less digitally skilled - as I show below. Accordingly, it is necessary to explore other social makers that can complement the argument about the age split.

\section{Digital literary and critical thinking skills}

Education is pivotal for political participation (Verba \& Nie, 1987; Wolfinger \& Rosenstone, 1990). According to Putnam (2000, p. 186), "education is one of the most important predictors - usually, in fact, the most important predictor - of many forms of social participation - from voting to associational membership, to chairing a local committee, to hosting a dinner party to giving blood". Some argue that using digital media naturally translates into civic engagement (Cohen \& Kahne, 2012; Jenkins, 2009). Actions such as receiving information, disseminating of opinions, or writing posts set the foundation of online political participation, which has been associated to higher participation in elections (ibid). Alternative research suggests that exposure to digital literacy, defined as the "minimal set of skills that will enable the user to operate effectively with software tools, or in performing basic information retrieval tasks" (Buckingham, 2010, p. 60), gives users the necessary skills to reason and evaluate digital information, thus being useful for better civic engagement (Buckingham, 2003; Hobbs, 2011). But as Buckingham (2010) notes, existing cultural values that justify how efficiently digital tools are being used are equally important (ibid). Accordingly, digital literacy encompasses being able to make efficient use of digital media. Nevertheless, these two approaches are not incompatible and, in some 
cases, teach digital skills based on existing digital activity and interests of users has proved to be valid (Martens \& Hobbs, 2015).

Net enrolment to primary school was $90 \%$ in 2017 . However, net enrolment to upper secondary school fell drastically to $38.75 \%$ (2014), and only $13.13 \%$ of students progressed to tertiary education (2017) (UNESCO, 2020). CSOs and citizens who participated in the study strongly emphasised the importance of education (including political education) and digital literacy, but both groups of respondents focused on different aspects of education. Ordinary citizens tended to stress the educational and digital gap that exists between those with a higher degree of formal education and those with lower degrees, especially those who have not completed upper secondary school - as the net enrolment statistics show, the largest gap is between primary and upper secondary education. This point of view was mostly shared, more specifically, by those with more formal education, like a young respondent with a university degree: "I think the first important thing is education. The more we understand, social media will have more advantage [sic], but for the less educated... I don't think it's much of an advantage for them. They waste their time" (Participant 208, July 2019). Regarding political literacy, data is less conclusive and the main narrative among citizens, even among with higher education, is that knowledge on politics is generally "poor" (Participant 206, July 2019) - a weakness that literature stresses (Dy, 2013). Lack of political literacy, on the one hand, impacts how much citizens know about the latest political development and, on the other hand, it also impacts how they interact with the constant influx of information they are exposed to: "people normally read headlines only; they skip the body of the text" (Participant 105, June 2019) when they check their Facebook feeds, observed a political analyst.

As a researcher, I encountered this challenge, and some participants asked me to read out loud the consent form because they were "lazy to read" it (Participant 212, August 2019), or to synthesise its context and explain it to them (Participant 210, July 2019). What these two respondents had in common is that they both were adults and neither of them had completed primary school. General education is therefore a first and fundamental step to understand the digital divide, and it "starts from home, from school, from the society" (Participant 302, July 2019).

All CSOs endorsed the aforementioned education gap. More specifically, their general narrative focused on the development of critical thinking skills, more than just general education - without undermining the role of general (and political) knowledge. To them, critical thinking is the decisive factor that differentiates users who just consume information and those who consume information and reflect about their digital activity. One informant (Participant 328, August 2019) was the spokesperson of an organisation that, among others, provides digital training that is specifically designed to improve critical thinking skills and, in his view, thinking critically filters the information users receive via social media platforms; SNS platforms like Facebook are not media (in its traditional approach), but a platform with a large amount of unfiltered messages - many of them without source - that, sometimes, intentionally manipulate facts.

During interviews with ordinary citizens, respondents showed their critical engagement through reflexive engagement with online media, scepticism to believe 
what they read until they can confirm it through other sources, and their capacity to judge sources. Those who showed more critical engagement with online information are also those who tended to be more politically active. Being politically active means that respondents engage or had engaged in political activities that go beyond the passive reception of news and information; for example, respondents who, thanks to digital media, had learnt about political rallies organised by the CNRP and the CPP, and had attended both so they could have an informed opinion (Participant 208, July 2019). However, critical thinking did not always correlate with higher education. For example, a young respondent (Participant 216, August 2019) did not have a secondary school diploma, but her experience working for an NGO, support for her colleagues, and being autodidactic allowed her to develop strong critical thinking skills that now she uses to make an efficient use of digital media at work, and also in her private life. Therefore, while those with a high school diploma are in a position of advantage, this may not always be the case, and with proper training, critical thinking skills can be acquired.

Critical thinking skills are also crucial to benefit from another of the major benefits of social networking sites: networking and interacting with other civil society actors. According to a board member of a political party (Participant 315, August 2019), his party interacts with youth more easily, mostly due to the digital literacy gap between youth and adults, and because youth can use digital resources with specific purposes:

"This is one of the things that we learn by experience, especially during campaigning and elections; the middle-aged do not have much access to smartphones or cannot use them, so they lack information about us... they do not know us". Later, he added that, "when people approach us and want to become new members... it is mostly young people because they observe us on Facebook; many of them, about $80 \%$ have been following us for some years. When they decide to join us, they already have information."

Altogether, ordinary citizens and CSOs highly emphasised the importance of education. Those with a lower level of formal education demonstrated that they had benefited from digital media, especially to gain access to more - and more diverse sources of political information. However, as a general rule, they showed low active engagement with politics; their actions were mostly passive and limited to receiving new inputs and having political conversations (face to face) with close friends or relative. Those with higher levels of formal education also stressed access to information as the major advantage. No evidence was found of new forms of engagement, and digital tools mostly allow citizens to replicate offline actions in the online space - like receiving information and talking to other people - and also to complement offline participation. For example, Facebook helped some participants to take part in political rallies. Therefore, it can be argued that digital media has made participation more inclusive, especially among those with less education, who were able to engage in politics for the first time, on some occasions.

The fundamental difference regarding education is that those who were able to analyse digital media critically were more likely to engage more actively in politics. Critical thinking was highly stressed by CSOs, and informants provided evidence: 
those who demonstrated to think critically about their digital inputs were more politically active. Though not exclusively, respondents with higher critical thinking skills were those with more formal education, and also young respondents. All in all, this reveals that regardless of the fact that those with lower formal education have also benefited from digital democracy, it is a factor that also contributes to the digital divide. Therefore, these finding are in line with previous research that indicates that more education is indicative of higher political participation (Buckingham, 2003; Hobbs, 2011), but what this study highlights is that critical thinking is what makes education such a relevant factor; critical thinking is likely to indicate how citizens engage with digital democracy, not only that they engage with it. Those with lower critical thinking skills tend to be shallow and they are more susceptible to be victims of threats like disinformation. Education is therefore a contributing factor to the digital divide in Cambodia.

\section{The urban-rural divide}

The urban-rural split is another important factor to analyse the digital divide. In 2019, $76 \%$ of Cambodia's citizen lived in rural areas (Smith \& Cruz, 2018). Therefore, in quantitative terms, a large proportion of citizens live in rural areas. However, two factors have narrowed the gap between the two over the last years: first, a substantial number of rural citizens who have migrated to the city, especially to Phnom Penh, to work or study. Second, because of SNS: digital media "allowed political protest in urban factories to resonate more widely among the rural electorate which constituted the ruling party's support base" (Hughes \& Eng, 2019, p. 366). These two combined have meant that more rural citizens now live in the city - where most of opposition political movements have originated - and, thanks to the internet, they can inform their relatives in the province (Hughes \& Eng, 2018).

Regardless of the importance of the geographical divide, results from this study is less conclusive since all respondents were residing in Phnom Penh - this selection was made purposively due to the limited resources. However, many participants that were interviewed were originally from rural villages, and according to some of them, there are two major problems in rural areas. First, infrastructure according to a political analyst, this gap is closing very slowly (Participant 106, August 2019), but rural areas are still poorly connected to the electrical grid (37\%) (Smith \& Cruz, 2018), and connection to the internet is slow: "sometimes, it does not work well in the province [the internet connection]; in the city, internet works better. If I go to my house [in the province], I cannot use the internet that much (Participant 215 , July 2019). The other main problem that respondents identified was that, in rural areas, literacy rates and formal education are lower: "It's also because of education; there is no activity to connect the gap between rich and the poor [people in rural areas]" said a political analyst. However, due to the above-mentioned limitations, these views could not be contrasted with rural villagers. These outcomes are, therefore, less specific.

\section{CONCLUSION}

This article has addressed political participation in the digital era and has also presented age, education and the urban-rural split as factors that contribute to the digital divide in Cambodia, especially education. Digital democracy has had - and 
still has - a remarkable impact on political participation, mostly because digital media has facilitated access to a much wider range of narratives and political information that, ultimately, has made civil society more politically informed, and has also created networks that have reinforced people's political engagement. Given Cambodia's lack of democratic tradition before the PPA (Chandler, 2009; Strangio, 2020), and partially failed democratic transition after 1991 (Chea, 2013; Peou, 1998c), it can be argued that digital democracy became an opportunity to overcome Cambodia's lack of democratic tradition, especially from the perspective of civil society to make governance more plural and inclusive.

However, challenges like surveillance or the media crackdown quickly emerged as challenges and diluted the wave of optimism that had been created and made digital media appear as liberation technology (Diamond, 2010). Such dynamic with notable differences - reassembled cases like the Arab Spring and, more importantly, the "winter" that followed after the revolutions (Phillips, 2012). The digital divide has proven to be another challenge to digital democracy - one that is often less visible or, at least, less mediatic - that has highlighted how existing social markers such as age or education have a direct impact on people's use of digital media with political ends. Broadly speaking, digital media has improved opportunities for political participation, but not all citizens can embrace these opportunities equally, thus creating a gap between those who benefit more and those who benefit less from digital media with political aims. Given existing limitations, this article has addressed age, education, and the urban-rural split, but the digital divide is not limited to these three variables. Income; gender; origins are variables that also contribute to the divide.

Finally, this case study has stressed that digital democracy has its own opportunities and challenges, which are highlighted in the debate on whether digital democracy improves or hinders democracy. The Cambodia case has shown that challenges to digital democracy are currently outshining opportunities. However, this does not make opportunities less valid. Put differently, opportunities and challenges coexist, thus making the analysis of digital democracy more plausible. Therefore, the debate on the democratisation capabilities of digital democracy should not be polarising, since there will always be new opportunities and challenges. Accordingly, the sceptical narrative (Gladwell, 2010; Guess et al., 2018; Morozov, 2011) offers a more realistic standpoint to analyse digital democracy: it supports digital technology to improve democracy and endorses its opportunities but, at the same time, is deeply concern about challenges. As Mukherjee (2018) puts it, we should be technosupporter sceptics.

\section{Notes}

\footnotetext{
i Facebook as a platform, without considering that, nowadays, Facebook owns Instagram and WhatsApp.

ii We Are Social (2020) offers one of the most comprehensive datasets on the digital habits and trends, which is published yearly, thus making it a great tools for comparative purposes.

iii The CNRP was a newly created party (2012) as a result of the merger between Sam Rainsy Party and Human Rights Party.
} 


\section{REFERENCES}

Al Jazeera. (2013). Cambodia PM Hun Sen claims election victory. Retrieved from http://america.aljazeera.com/articles/2013/7/28/cambodia-pm-hunsenclaimselectionvictory.html

Altheide, D. L. (2013), Media logic, social control, and fear: Media logic, social control, and Fear. Communication Theory, 23(3), 223-238. Retrieved from https://doi.org/10.1111/comt.12017

Alves, M. H. M. (1990). State and opposition in military Brazil. Texas: University of Texas Press.

Asia Foundation. (2016). Facebook Cambodia Civic Insights - November 2015 (pp. 1-8). Asia Foundation. Retrieved from https://asiafoundation.org/resources/pdfs/FacebookCambodiaCivicInsightsRep ortNovember2015.pdf

Ayres, D. M. (2000). Anatomy of a crisis: Education, development, and the state in Cambodia, 1953-1998. University of Hawai'i Press.

Bennett, W. L. (2012), The personalization of politics: Political identity, social media, and changing patterns of participation. The ANNALS of the American Academy of Political and Social Science, 644(1), 20-39. Retrieved from https://doi.org/10.1177/0002716212451428

Bong, C., \& Sen, C. (2017). Research brief: Youth political participation in Cambodia. Berlin: Konrad-Adenauer-Stiftung. Retrieved from https://www.kas.de/c/document_library/get_file?uuid=b71a2520-4428-56c4c937-b56948c9bde0\&groupId=252038

Brandtzæg, P. B., \& Heim, J. (2009), Why people use social networking sites. Online Communities and Social Computing, 143-152. Retrieved from https://link.springer.com/chapter/10.1007/978-3-642-02774-1_16

Buckingham, D. (2003). Media education: Literacy, learning, and contemporary culture. Polity Press; Distributed in the USA by Blackwell Pub.

Buckingham, D. (2010), Defining digital literacy. In Medienbildung in neuen Kulturräumen. VS Verlag für Sozialwissenschaften (pp. 59-71).

Cambodian Centre for Independent Media. (2018, May 4), Cambodia: How to dismantle a democracy? Retrieved from https://www.seapa.org/cambodiahow-to-dismantle-a-democracy/

Casteltrione, I. (2015), The Internet, social networking Web sites and political participation research: Assumptions and contradictory evidence. First Monday. Retrieved from https://doi.org/10.5210/fm.v20i3.5462

Çelik, B. (2020), Screening for Erdoğanism: Television, post-truth and political fear. European Journal of Communication, 026732312090368. Retrieved from https://doi.org/10.1177/0267323120903680

Chandler, D. (2009). A history of Cambodia. Westview Press. Retrieved from http://public.ebookcentral.proquest.com/choice/publicfullrecord.aspx? $\mathrm{p}=9277$ 51

Chandler, D. P. (1993). The tragedy of Cambodian history: Politics, war, and revolution since 1945. Yale: Yale University Press.

Chea, S. (2013). The Paris Peace Accords and the development of democracy in Cambodia. Pannasastra: University of Cambodia. Retrieved from 
http://www.academia.edu/3818289/The_Paris_Peace_Accords_and_the_Devel opment_of_Democracy_in_Cambodia

Chhim, S. (2012), Baksbat (Broken Courage): The development and validation of the inventory to measure Baksbat, a Cambodian trauma-based cultural syndrome of distress. Culture, Medicine, and Psychiatry, 36(4), 640-659. Retrieved from https://doi.org/10.1007/s11013-012-9279-6

Chhim, S. (2013). Baksbat (Broken Courage): A trauma-based cultural syndrome in Cambodia. Medical Anthropology, 32(2), 160-173. Retrieved from https://doi.org/10.1080/01459740.2012.674078

Chinn, M. D., \& Fairlie, R. W. (2006), The determinants of the global digital divide: A cross-country analysis of computer and internet penetration. Oxford Economic Papers, 59(1), 16-44. Retrieved from https://doi.org/10.1093/oep/gp1024

CIA. (2020). East Asia/Southeast Asia: Cambodia-The World Factbook-Central Intelligence Agency. Retrieved from https://www.cia.gov/library/publications/the-world-factbook/geos/cb.html

Cohen, C. J., \& Kahne, J. (2012). Participatory politics: New media and youth political action (pp. 1-42). Youth and Participatory Politics Research Network, Mills College School of Education. Retrieved from http://ypp.dmlcentral.net/sites/all/fi les/publications/YPP_Survey_Report_FULL.pdf

COMFREL. (2008). 2008 National Assembly Elections (pp. 1-108). COMFREL. Retrieved from https://comfrel.org/english/final-assessment-and-report-on-the2008-national-assembly-elections/

Croissant, A. (2018), Cambodia in 2017: Descending into dictatorship? Asian Survey, 58(1), 194-200. Retrieved from https://doi.org/10.1525/as.2018.58.1.194

Diamond, L. (2010), Liberation technology. Journal of Democracy, 21(3), 69-83. Retrieved from https://doi.org/10.1353/jod.0.0190

Diehl, T., Barnidge, M., \& Gil de Zúñiga, H. (2019), Multi-platform news use and political participation across age groups: Toward a valid metric of platform diversity and its effects. Journalism \& Mass Communication Quarterly, 96(2), 428-451. Retrieved from https://doi.org/10.1177/1077699018783960

DiMaggio, P., \& Hargittai, E. (2001). From the 'Digital Divide' to 'Digital Inequality': Studying internet use as penetration increases. New Jersey: Princeton University Press. Retrieved from https://culturalpolicy.princeton.edu/sites/culturalpolicy/files/wp15_dimaggio_ hargittai.pdf

Dryzek, J. S., \& List, C. (2003), Social Choice Theory and deliberative democracy: A reconciliation. British Journal of Political Science, 33(01), 1-28. Retrieved from https://doi.org/10.1017/S0007123403000012

Dy, K. (2013). Challenges of teaching genocide in Cambodian secondary schools. Clark Digital Commons. Retrieved from http://ticambodia.org/library/wpcontent/files_mf/1436954165ChallengesofteachingGenocideinCambodiainsec ondaryschool.pdf

EU Election Observation Mission. (2003). EU Election Observation Mission Cambodia 2003. Final Report on the Elections of the Members of the National Assembly (pp. 1-92). European Union. Retrieved from http://www.epgencms.europarl.europa.eu/cmsdata/upload/f12fd8a0-8f18- 
4cec-a47c-736a8456d8f0/Cambodia-elections-27-July-2003-EU-EOMreport.pdf

Freedom House. (2019, January 30). Freedom in the world 2019; Cambodia. Retrieved from https://freedomhouse.org/report/freedomworld/2019/cambodia

Freeman, J., \& Quirke, S. (2013), Understanding E-Democracy; government-led initiatives for democratic reform. Journal of EDemocracy, 5(2), 141-154.

Frost, F. (1992). The Peace Process in Cambodia: The First Stage (pp. 1-58). Department of the Parliamentary Library (Australia). Retrieved from https://www.aph.gov.au/binaries/library/pubs/bp/1992/92bp14.pdf

Gibson, R., \& Cantijoch, M. (2013), Conceptualizing and measuring participation in the age of the internet: Is online political engagement really different to offline? The Journal of Politics, 75(3), 701-716. Retrieved from https://doi.org/10.1017/S0022381613000431

Gil de Zúñiga, H., Jung, N., \& Valenzuela, S. (2012), Social media use for news and individuals' social capital, civic engagement and political participation. Journal of Computer-Mediated Communication, 17(3), 319-336. Retrieved from https://doi.org/10.1111/j.1083-6101.2012.01574.x

Ginsberg, R., \& Lyche, L. F. (2008), The Culture of Fear and the Politics of Education. Educational Policy, 22(1), 10-27. Retrieved from https://doi.org/10.1177/0895904807311293

Gladwell, M. (2010), Small Change. The New Yorker. Retrieved from https://www.newyorker.com/magazine/2010/10/04/small-change-malcolmgladwell

Guess, A., Nyhan, B., Lyons, B., \& Reifler, J. (2018). Avoiding the echo chamber about the echo chambers: Why selective exposure to like-minded political news is less prevalent than you think. Knight Foundation. Retrieved from https://kf-site-

production.s3.amazonaws.com/media_elements/files/000/000/133/original/To pos_KF_White-Paper_Nyhan_V1.pdf

Hargittai, E. (2010), Digital $\mathrm{Na}(\mathrm{t})$ ives? Variation in internet skills and uses among members of the "Net Generation". Sociological Inquiry, 80(1), 92-113. Retrieved from https://doi.org/10.1111/j.1475-682X.2009.00317.x

Heder, S. (1995), Cambodia's democratic transition to neoauthoritarianism. Current History, 94(596), 425-429.

Hobbs, R. (2011). Digital and media literacy: Connecting culture and classroom. Thousand Oaks CA: Corwin Press.

Hughes, C. (2013). Understanding the Elections in Cambodia 2013. Graduate School of Global Studies, Sophia University. Retrieved from http://dept.sophia.ac.jp/g/gs/wpcontent/uploads/2015/06/b98c8184d35f9b156df22f210dd322a2.pdf

Hughes, C., \& Eng, N. (2018), Facebook, contestation and poor people's politics: Spanning the urban-rural divide in Cambodia? Journal of Contemporary Asia, 1-24. Retrieved from https://doi.org/10.1080/00472336.2018.1520910

Hughes, C., \& Eng, N. (2019), Facebook, contestation and poor people's politics: Spanning the urban-rural divide in Cambodia? Journal of Contemporary Asia, 49(3), 365-388. Retrieved from https://doi.org/10.1080/00472336.2018.1520910 
Human Rights Watch. (2018, January 18). Cambodia: Crackdown crushes media, opposition. Human Rights Watch. Retrieved from https://www.hrw.org/news/2018/01/18/cambodia-crackdown-crushes-mediaopposition

Huntington, S. P. (1993). The third wave: Democratization in the late twentieth century (1. paperback print). Oklahoma: Univ. of Oklahoma Press.

Jacques, C., \& Lafond, P. (2007). The Khmer Empire: Cities and sanctuaries, fifth to the thirteenth centuries. River Books.

Jayasuriya, K., \& Rodan, G. (2007), Beyond hybrid regimes: More participation, less contestation in Southeast Asia. Democratization, 14(5), 773-794. Retrieved from https://doi.org/10.1080/13510340701635647

Jenkins, H. (2009). Confronting the Challenges of Participatory Culture. Cambridge, Massachusetts: The MIT Press. Retrieved from http://www.oapen.org/download?type=document\&docid=1004003

Kidron, C. A., \& Kirmayer, L. J. (2019), Global mental health and idioms of distress: The paradox of culture-sensitive pathologization of distress in Cambodia. Culture, Medicine, and Psychiatry, 43(2), 211-235. Retrieved from https://doi.org/10.1007/s11013-018-9612-9

Kiernan, B. (2008). The Pol Pot regime: Race, power, and genocide in Cambodia under the Khmer Rouge, 1975-79. New Haven: Yale University Press. Retrieved from http://public.eblib.com/choice/publicfullrecord.aspx?p=3420467

Lamb, K. (2018, July 6), Cambodia 'fake news' crackdown prompts fears over press freedom. The Guardian. Retrieved from https://www.theguardian.com/world/2018/jul/06/cambodia-fake-newscrackdown-prompts-fears-over-press-freedom

Lee, S. H. (2017), Digital democracy in Asia: The impact of the Asian internet on political participation. Journal of Information Technology \& Politics, 14(1), 62-82. Retrieved from https://doi.org/10.1080/19331681.2016.1214095

MacKinnon, M. P. (2007). Lost in Translation: (Mis)Understanding Youth Engagement (p. 54). Canadian Policy Research Networks. Retrieved from https://www.researchgate.net/publication/252223855_Lost_in_Translation_Mi sUnderstanding_Youth_Engagement

Marichal, J. (2013), Political Facebook groups: Micro-activism and the digital front stage. First Monday, 18(12). Retrieved from https://doi.org/10.5210/fm.v18i12.4653

Martens, H., \& Hobbs, R. (2015), How media literacy supports civic engagement in a digital age. Atlantic Journal of Communication, 23(2), 120-137. Retrieved from https://doi.org/10.1080/15456870.2014.961636

McCabe, S., \& Haffner, A. (2020, March 18), 50 years on, was the 1970 coup the defining event in Cambodia's history? Southeast Asia Globe. Retrieved from https://southeastasiaglobe.com/lon-nol-coup-cambodia/

McCargo, D. (2018), The trouble with turnout at Cambodia's election. Asia Times. Retrieved from https://asiatimes.com/2018/07/the-trouble-with-turnout-atcambodias-election/

Meijer, A., Burger, N., \& Ebbers, W. E. (2009), Citizens4Citizens: Mapping participatory practices on the internet. Electronic Journal of E-Government, 7(1), 99-112. 
Melo, D. F., \& Stockemer, D. (2014), Age and political participation in Germany, France and the UK: A comparative analysis. Comparative European Politics, 12(1), 33-53. Retrieved from https://doi.org/10.1057/cep.2012.31

Morgenbesser, L. (2017), The failure of democratisation by elections in Cambodia. Contemporary Politics, 23(2), 135-155. Retrieved from https://doi.org/10.1080/13569775.2016.1230317

Morozov, E. V. (2011). The net delusion: The dark side of internet freedom (1. ed). Public Affairs.

Mossberger, K., Tolbert, C. J., \& Stansbury, M. (2003). Virtual Inequality: Beyond the Digital Divide. Washington D.C.: Georgetown University Press. Retrieved from https://books.google.co.uk/books/about/Virtual_Inequality.html?id=lEzJlG0B yJgC\&source=kp_book_description\&redir_esc $=\mathrm{y}$

Mukherjee, A. S. (2018). The Need for 'Techno-Supporting Skeptics'. MIT Sloan Management Review. Retrieved from https://sloanreview.mit.edu/article/theneed-for-techno-supporting-skeptics/

Murdoch, S. (2010), Destructive activism: The double-edged sword of digital tactics. In Digital Activism Decoded: The new mechanics of change (pp. 137-148). International Debate Education Association. Retrieved from https://murdoch.is/papers/digiact10all.pdf

Nohlen, D., Grotz, F., \& Hartmann, C. (Eds.). (2001). Elections in Asia and the Pacific: A data handbook. Oxford: Oxford University Press.

Norris, Donald. F. (2010). E-government... Not e-governance... Not e-democracy not now!: Not ever? 339-346. Retrieved from https://doi.org/10.1145/1930321.1930391

Nyabola, N. (2018). Digital democracy, analogue politics: How the internet era is transforming Kenya. London: ZED Books.

Pak, K., Horng, V., Eng, N., Ann, S., Kim, S., Knowles, J., \& Craig, D. (2007). Accountability and neo-patrimonialism in Cambodia: A critical literature review. Cambodia Development Resource Institute. Retrieved from https://cdri.org.kh/wp-content/uploads/wp34e.pdf

Papacharissi, Z. A. (2013). A Private Sphere: Democracy in a Digital Age. Wiley. Retrieved from http://grail.eblib.com.au/patron/FullRecord.aspx?p=1180919

Peou, S. (1998a), Cambodia in 1997: Back to Square One? Asian Survey, 38(1), 6974.

Peou, S. (1998b), The Cambodian Elections of 1998 and Beyond: Democracy in the Making? Contemporary Southeast Asia, 20(3), 279-297.

Peou, S. (1998c), The Cambodian Elections of 1998 and Beyond: Democracy in the Making? Contemporary Southeast Asia, 20(3), 279-297.

Phillips, J. (2012). The Arab Spring Descends into Islamist Winter: Implications for U.S. Policy. The Heritage Foundation. Retrieved from https://www.heritage.org/report/the-arab-spring-descends-islamist-winterimplications-us-policy

Phong, K., Srou, L., \& Sola, J. (2016). Mobile Phones and Internet Use in Cambodia 2016 (pp. 1-42). Asia Foundation. Retrieved from https://asiafoundation.org/wp-content/uploads/2016/12/Mobile-Phones-andInternet-Use-in-Cambodia-2016.pdf

Putnam, R. D. (2000), Bowling alone: The collapse and revival of American community. Proceedings of the 2000 ACM Conference on Computer 
Supported Cooperative Work - CSCW '00, 357. Retrieved from https://doi.org/10.1145/358916.361990

Scharf, M. (2007), Long-term effects of trauma: Psychosocial functioning of the second and third generation of Holocaust survivors. Development and Psychopathology, 19(02). Retrieved from https://doi.org/10.1017/S0954579407070290

Schoenberger, L., Beban, A., \& Lamb, V. (2018). Authoritarian Rule Shedding its Populist Skin: How loss of independent media in the 2017 crackdown shapes rural politics in Cambodia. 1021. Retrieved from https://www.tni.org/files/articledownloads/erpi_cp_70_schoenberger_et_al.pdf

Shahbaz, A. (2018). Freedom on the Net 2018-The Rise of Digital Authoritarianism. Freedom House. Retrieved from https://freedomhouse.org/report/freedomnet/freedom-net-2018/rise-digital-authoritarianism

Shirky, C. (2011), The political power of social media. Foreign Affairs, 90(1), 28-41.

Simon, J., Bass, T., \& Boelman, V. (2017). Digital Democracy, the tools transforming political engagement (pp. 1-99). Nesta. Retrieved from https://media.nesta.org.uk/documents/digital_democracy.pdf

Smith, A., \& Cruz, G. (2018). Rural population (\% of total population)—Cambodia. GSMA. Retrieved from https://data.worldbank.org/indicator/SP.RUR.TOTL.ZS?locations=KH

Soeung, S. (2013). Social Media's Growing Influence on Cambodian Politics. East West Center. Retrieved from https://scholarspace.manoa.hawaii.edu/bitstream/10125/29717/1/APB\%20no. $\% 20222 . p d f$

Soeung, S. (2016), Cambodia in 2015: Accommodating generational change. In Southeast Asian Affairs 2016 (pp. 107-129). ISEAS-Yusof Ishak Institute.

Strangio, S. (2020). Cambodia, from Pol Pot to Hun Sen and Beyond. New Haven: Yale University Press.

Teng, K. (2015). Clientelism and Party Institutionalization in PostAuthoritarian/Post-Conflict Regimes: The Case of Cambodia. Columbus: Ohio State University]. Retrieved from https://etd.ohiolink.edu/!etd.send_file?accession=ohiou1430869960\&dispositi on=inline

Tucker, J. A., Theocharis, Y., Roberts, M. E., \& Barberá, P. (2017), From liberation to turmoil: Social media and democracy. Journal of Democracy, 28(4), 46-59. Retrieved from https://doi.org/10.1353/jod.2017.0064

Um, K. (2014), Cambodia in 2013: The Winds of Change. Southeast Asian Affairs. Retrieved from https://muse.jhu.edu/article/552388/pdf

Un, K. (2005), Patronage politics and hybrid democracy: Political change in Cambodia, 1993-2003. Asian Perspective, 29(2), 203-230.

Un, K. (2015), The Cambodian People Have Spoken. Has the Cambodian People's Party Heard? In Southeast Asian Affairs 2015 (pp. 102-116). ISEAS-Yusof Ishak Institute Singapore. Retrieved from https://doi.org/10.1355/9789814620598-009

UNESCO. (2020). UIS Statistics. UNESCO Institute for Statistics. Retrieved from http://data.uis.unesco.org/Index.aspx?queryid=144 
van Deth, J. W. (2016). What is Political Participation? (Vol. 1). Oxford: Oxford University Press. Retrieved from https://doi.org/10.1093/acrefore/9780190228637.013.68

van Dijk, J. A. G. M. (2006), Digital divide research, achievements and shortcomings. Poetics, 34(4-5), 221-235. Retrieved from https://doi.org/10.1016/j.poetic.2006.05.004

van Dijk, S., Johhannes. (2012), Digital democracy: Vision and reality. In Public Administration in the Information Age: Revisited-Innovation and the Public Sector. (pp. 49-62). IOS Press, Incorporated. Retrieved from http://site.ebrary.com/id/10641759

Verba, S., \& Nie, N. H. (1987). Participation in America: Political democracy and social equality. Chicago: University of Chicago Press.

Vickery, M. (1999). Cambodia: 1975-1982. Silkworm.

Volkan, V. D. (2001), Transgenerational Transmissions and Chosen Traumas: An Aspect of Large-Group Identity. Group Analysis, 34(1), 79-97. Retrieved from https://doi.org/10.1177/05333160122077730

Vong, M., \& Hok, K. (2018), Facebooking: Youth's everyday politics in Cambodia. South East Asia Research, 26(3), 219-234. Retrieved from https://doi.org/10.1177/0967828X17754113

We Are Social. (2020). Digital 2020 Cambodia. We Are Social. Retrieved from https://datareportal.com/reports/digital-2020-cambodia?rq=cambodia

Weaver Lariscy, R., Tinkham, S. F., \& Sweetser, K. D. (2011), Kids These Days: Examining Differences in Political Uses and Gratifications, Internet Political Participation, Political Information Efficacy, and Cynicism on the Basis of Age. American Behavioral Scientist, 55(6), 749-764. Retrieved from https://doi.org/10.1177/0002764211398091

Whiteley, P. (2005). Citizenship education longitudinal study second literature review,. DfES Publications. Retrieved from https://www.nfer.ac.uk/citizenship-education-longitudinal-study-secondliterature-review-citizenship-education-the-political-science-perspective/

Wijers, G. D. M. (2010), Determinants of the digital divide: A study on IT development in Cambodia. Technology in Society, 32(4), 336-341. Retrieved from https://doi.org/10.1016/j.techsoc.2010.10.011

Wolfinger, R., \& Rosenstone, S. (1990). Who Votes? Retrieved from https://www.degruyter.com/doi/book/10.12987/9780300161847

Zakaria, F. (2007). The future of freedom: Illiberal democracy at home and abroad. Retrieved from https://www.overdrive.com/search?q=DB0B0F50-5454-4E90A0CF-191D40F32BC1 